\title{
Green Synthesis of Silver Nanoparticles by Grapefruit's Peel and Effect on Superoxide dismutase Enzyme Activity and Growth of Cucumber Plants Inoculated with Rhizoctonia solani
}

\author{
RAMESH FAGHIHI ${ }^{1}$, KAMBIZ LARIJANI $^{2}$, VAHID ABDOSS ${ }^{1 *}$ and PEJMAN MORADI ${ }^{3}$ \\ 'Department of Horticulture, Science and Research Branch, Islamic Azad University, Tehran, Iran. \\ ${ }^{2}$ Department of Chemistry, Science and Research Branch, Islamic Azad University, Tehran, Iran. \\ ${ }^{3}$ Department of Horticultural Sciences, Saveh Branch, Islamic Azad University, Saveh, Iran. \\ ${ }^{*}$ Corresponding author E-mail: abdusivahid @ gmail.com
}

http://dx.doi.org/10.13005/ojc/330614

(Received: Junuary 05, 2017; Accepted: March 02, 2017)

\begin{abstract}
The experiment was conducted during 2015 to Green synthesis of silver nanoparticles using Grapefruit's peel extract. In addition, we find out the effect of silver nanoparticles on dampingoff caused by Rhizoctonia solani in cucumber plants. The silver nanoparticles characterized for their size and shape using scanning electron microscopy and transmission electron microscopy(TEM), respectively. X-ray diffraction spectroscopies (XRD) were evaluated to determine the concentration of metal ions. Results showed that the size of nanoparticle was 5-65 $\mathrm{nm}$ and the average size was determined $55.02 \mathrm{~nm}$ with shape of spherical. In addition, the impact of silver nanoparticles was investigated by Grapefruit's peel on response of cucumber plants inoculated with Rhizoctonia solani.Variables analyzed were superoxide dismutase (SOD) activity, fresh and dry weight of root and shoot. The data analysis revealed that fresh and dry weights of roots and shoots were significantly higher in treatments containing 30,50 and $70 \mathrm{grL}^{-1}$ of nanoparticles compared to the control plants $(P<0.01)$. The highest superoxide dismutase activity was observed in $70 \mathrm{grL}^{-1}$ nanoparticles treatment after 48 hours. however, a significantly higher percentage of disease damage was appeared in control plant, while symptoms were observed in treated plants with nanosilver. The results of this study suggest that enhancement of defense enzyme.
\end{abstract}

Keywords: Green synthesis, Silver nanoparticles, X-ray diffraction spectroscopy (XRD), Transmission electron microscopy (TEM), superoxide dismutase (SOD), Rhizoctonia solani.

\section{INTRODUCTION}

Green Synthesis of Nano is a reliable method for the nanoparticles synthesis and environmentally friendly approach considered.
About 15 years ago, it is clear that nanoscale materials can exhibit useful properties. Consequently, the number of consumer products employing nanotechnology has increased by this technology ${ }^{1}$. 
Among all method, since, nanoparticles synthesis expedited to developing route, due to their physical, chemical and biological qualities nanotechnology products will be more available. The size of nanoparticle are up to $100 \mathrm{~nm}$. Its size, shape and distribution look more different with larger particle ${ }^{2,3}$.

There are three method for preparation of nanoparticles; Physical, chemical and biological ${ }^{4}$. Due to expensive physical and chemical methods, nanoparticles synthesized through microorganisms and plant extracts are some common techniques ${ }^{5,6,7,8,9}$. There are three eco-friendliness ways of green synthesis such as using fungi, eukaryotes or bacteria, virus-like particles and plant extract ${ }^{6,10,11}$.

Nanocrystals metal such as $\mathrm{Ag}, \mathrm{Au}$, and $\mathrm{Pt}$ are used in pharmaceutical and medical area products, which directly affect human health. Therefore, the importance of green synthetic is due to cheap source, less-toxic, inexpensive material and unique properties such as anti-inflammatory activities as well as good conductivity, which could be used in cosmetic, and food industry ${ }^{12,13 .}$

Much research numerous studies had been done on green synthesis of silver nanoparticles and their size and shape (Table 1) 14, 15 16, 17, 18, 19.

Characterization methods have been illustrate by Fourier transforms infrared spectroscopy FTIR, transmission electron microscopy (TEM), UVvisible spectrophotometer, scanning electron microscopy (SEM), X-ray diffraction Analysis (XRD), and energy dispersive spectroscopy (EDS) $20,21,22,23,24,25$.

Cucumis sativus is widely important vegetables in the all over world and different regions of Iran. Many agents such as fungi and bacteria attack cucurbit. Rhizoctonia solani is the plant pathogen fungi that can attack Cucurbits cause damping-off. Presence of fungicide resistant have increased by indiscriminate using of chemical fungicides ${ }^{26}$.

Damping off cause economic losses by attacking vegetable crop like cucumber. Likewise, it is a horticultural disease that caused by some different pathogens like Rhizoctonia solani that kill or tender seedlings or seeds after or before they germinate. It is common in cool and wet conditions ${ }^{26}$.
Also, the use of fungicides increased production costs and environmental damage. There are different symptoms associated with damping off; this reflects the diversity of disease-causing organisms that can cause this condition ${ }^{27}$.

The aim of this study was evaluating the antifungal effects of silver nanoparticles derived from grapefruit peel against the fungus Rhizoctonia solani was carried.

\section{MATHERIALS AND METHODS}

\section{Environment condition}

The greenhouse experiment was conducted at Samandak Village located at Sari in Mazandaran province, Iran, during 2015. These are kept under controlled laboratory at $25-28^{\circ} \mathrm{C}$, with a photoperiod of $16 \mathrm{~h}$ of light/8 darkness and $70 \%$ $\mathrm{RH}$ at laboratory of horticulture, Science and Research Branch, Islamic Azad University, Tehran, Iran.

All of chemicals and reagents used in this study including; analytical grade and silver nitrate $\left(\mathrm{AgNO}_{3}, 99.9 \%\right)$ was prepared from Merek Company. The Grapefruit's peels were collected from a garden in sari(longitude: $53^{\circ} 52$ W 53 degrees 5 min. ; latitude: $36^{\circ} 42 \mathrm{~N} 36$ degrees $4 \mathrm{~min}$. ;132 m above sea level and an average annual temperature of $15^{\circ} \mathrm{C}$.

Double distilled water was used for solutions. All glassware used in experimental procedures were cleaned with double distilled water and dried.

\section{Extraction Procedure}

The Grapefruit's peel kept at a room temperature in the dark and in front of a fan to avoid any photochemical reactions for a day to remove the moisture until they were dried. then grounded in a mixer. Extract was obtained by adding $0.5 \mathrm{~g}$ Grapefruit's peel powder to $100 \mathrm{~mL}$ sterile distilled and heated for $20 \mathrm{~min}$. at $90^{\circ} \mathrm{C}$ using a steamer (Ben Murray).

After cooling, the extract was filtered using whatman No.1 then accurate concentration of $1 \mathrm{mM}$ silver nitrate (AgNO3, 99.9\%) was prepared by dissolving $0.0001 \mathrm{~g} \mathrm{AgNO}_{3}$ in $1000 \mathrm{ml}$ of Deionized 
water and stored in colored bottle. After that, $20 \mathrm{~mL}$ of extract, $80 \mathrm{ml}$ of $1 \mathrm{mM} \mathrm{AgNO}_{3}$ solution was added and kept in sunlight for 30 minutes. The color change observed stands as a preliminary confirmation for the formation of silver nanoparticles. The solution was centrifuged at $1000 \mathrm{rpm}$ per minute. The separated nanoparticles settled at the bottom were collected and washed thrice with deionized water, then dried in an oven at $60^{\circ} \mathrm{C}$ for 2 hours. The stabilized powder forms of the nanoparticles were stored for further characterization.

\section{Factor measurement of the nanoparticles}

Key factor such as $\mathrm{pH}$, plant extract concentration, metal solution concentration, size and shape of nanosilver, were measured.

$\mathrm{pH}$

$\mathrm{pH}$ is one of the important factor in the bio-formation of metallic nanoparticles. In this study we used $\mathrm{pH}(4,7,8,10)$ for green synthesis of silver nanoparticles using Grapefruit's peel extract.

\section{Temperature}

Temperature is one of the most important aspects of silver nanoparticles synthesis that can affect nature of nanoparticles formed. In this study used 3 Temperature $\left(40,50\right.$ and $\left.60^{\circ} \mathrm{C}\right)$ for green synthesis of silver nanoparticles using Grapefruit's peel extract.

\section{Characterization of AgNPs}

Silver Nanoparticles were characterized by UV-Vis spectra were recorded over the 300-800 nm range with a UV 1650 PCShimadzu B UV-Vis spectrophotometer, XRD studies were done by a Sifert XRD 3003 PD (Germany), Morphology of $\mathrm{Ag}$ nanoparticles was performed using transmission electron microscopy (TEM) image by means of a Philips EM 208 instrument with $100 \mathrm{kV}$ acceleration voltages.

\section{Different concentrations of Grapefruit's peel extract}

In this study used 3 concentrations (50:50, 40:60 and 20:80) for green synthesis of silver nanoparticles using Grapefruit's peel extract.
Plant material and using different concentration of treatment

The experiment was done in completely randomized block design with 4 treatments and three replication (10 plants per replication) on cucumber (Cucumis sativus L.) seeds variety of Vilmorin. Seed were disinfected in $70 \%$ ethanol for $3 \mathrm{~min}$, washed into double distillation water and cultured in pots $(40 \%$ sterile soil, $40 \%$ perlite and $20 \%$ coco peat). They were grown under temperature $\left(24 / 27^{\circ} \mathrm{C}\right.$-night/day), photoperiod $(16 / 8 \mathrm{~h})$ and humidity $(70 \%)$ and transferred to normal Hoagland solution. 30,50 and $70 \mathrm{~g} \mathrm{~L}^{-1}$ silver nanoparticles was applied to the plants when second leaves appear. Distilled water were consisted as control

\section{Preparation of culture fungal and inoculums}

Cucumber were also inoculated with Rhizoctonia solani after foliar spraying with nanosilver Isolated from infected cucumber seedlings, was prepared in the Islamic Azad University, Science and Research Branch, Tehran, Iran. $200 \mathrm{~cm}^{3}$ of washed sand, $200 \mathrm{~cm}^{3}$ of garden soil, $40 \mathrm{gr}$ corn flour and $80 \mathrm{ml}$ of distilled water were mixed in a $1000 \mathrm{ml}$ Erlenmeyer and were autoclaved at $121^{\circ} \mathrm{C}$ for 20 minutes.

\section{Growth factors}

Plants were uprooted at 12, 24, 48 and 72 $\mathrm{h}$ intervals. The shoots and roots of plants were collected in per pot for measuring fresh weight. They were weighed and then incubated in oven at $90^{\circ} \mathrm{C}$ for $72 \mathrm{~h}$ then were weighed.

\section{Enzyme extraction and SOD activity assay}

The shoots and roots of plants were collected in per pot at different time (12, 24, 48 and $72 \mathrm{~h}$ ) post-inoculation and immediately washed with Double distilled water and were stored at Liquid Nitrogen until used. The superoxide dismutase activity was measured by NBT method, as explained by Giannopolitis and Ries ${ }^{28}$.

Protein determination method was conducted by Bradford method ${ }^{29} .200 \mathrm{mg}$ Leaf samples were ground with liquid nitrogen and homogenized with phosphate buffer $(p H 7.0)$ and $0.5 \mathrm{mM}$ EDTA. Then it centrifuged at $18,000 \mathrm{rpm}$, $15 \mathrm{~min}$ at $4^{\circ} \mathrm{C}$ in rotor. $1500 \mu$ l of phosphate buffer (50 mM), $50 \mathrm{mM}$ sodium carbonate $(300 \mu \mathrm{l}), 12 \mathrm{mM}$ 
methionine ( $300 \mu \mathrm{l}$ ), $75 \mathrm{mM}$ nitro blue tetrazolium chloride ( $300 \mu \mathrm{l}), 1 \mathrm{mM}$ riboflavin $(300 \mu \mathrm{l})$ and 300 $\mu \mathrm{l}$ of the enzyme extract were used to measure the Superoxide dismutase activity. The absorbance of sample at $560 \mathrm{~nm}$ was recorded with a spectrophotometer. One unit of SOD enzyme activity causes $50 \%$ inhibition of NBT reduction.

\section{Disease assay}

Disease severity was calculated visually after the initial inoculation according to conventional method of Zhang et al., ${ }^{30}$. Symptomless plants scored as1, Less than 1/3damaged: 2, 2/3 damaged: 3 and more than 2/3 damaged: 4

\section{Data analysis}

These studies were conducted as completely randomized design with three replicate. Duncan test was used for mean comparison at $1 \%$. All statistical analyses were calculated using Minitab 16 Statistical software and the graphs were drawn in Microsoft Office Excel 2013.

\section{RESULTS}

\section{Change the color of silver nanoparticles}

Since Grapefruit's peel extracts was used, color change was occurred due to Ag+ reduce into Ag-NPs. Grapefruit's peel suspension was yellow but after adding $\mathrm{AgNO}_{3}$ (10 min.) it change to dark brown. Surface Plasmon resonance phenomenon might be corresponding to its reason (see Figure.1).

\section{$\mathrm{pH}$}

In this study used $4 \mathrm{pH}(4,7,8$ and 10) for green synthesis of silver nanoparticles using Grapefruit's peel extract. Results showed that $\mathrm{pH} 7$ were more effective than other $\mathrm{pH}$ (see Figure. 2).

\section{Temperature}

In this study used 3 Temperature $(40,50$ and $60^{\circ} \mathrm{C}$ ) for green synthesis of silver nanoparticles using Grapefruit's peel extract. The UV-Vis results showed that the best Temperature is $60^{\circ} \mathrm{C}$ (see Figure. 3).

Table. 1: Green synthesis of silver nanoparticles and their size and shape

\begin{tabular}{lll}
\hline & Shape and Size & References \\
\hline Acalypha indica & Spherical and 20-30 nm & Krishnaraj et al., 2010 \\
Allium sativum & Spherical and 4-22nm & Ahamed, et al., 201 \\
Aloe vera & spherical\& triangular with 50-350nm & Chandran, et al., 2006 \\
Azadirachta indica & sperrical, \& tringular with 7.5-65nm & Kasthuri, et al., 2009 \\
Boswellia ovalifoliolata & 30-40nm & Ankanna, et al., 2010 ${ }^{18}$ \\
Carica papaya & $25-50 \mathrm{~nm}$ & Jain, et al., 200919 \\
\hline
\end{tabular}

Table. 2: Mean square of studied growth parameters between silver nanoparticles treated and control cucumber plants inoculated with $R$. solani ${ }^{*}$ and ${ }^{\star *}$ Significant at the level of five and one percent

\begin{tabular}{lcccccc}
\hline SOC. & DF. & $\begin{array}{c}\text { Root dry } \\
\text { weight }\end{array}$ & $\begin{array}{c}\text { Shoot dry } \\
\text { weight }\end{array}$ & $\begin{array}{c}\text { Root fresh } \\
\text { weight }\end{array}$ & $\begin{array}{c}\text { Shoot fresh } \\
\text { weight }\end{array}$ & SOD \\
\hline Rep. & 2 & $0.210^{*}$ & $0.617^{*}$ & $0.8000^{* *}$ & $0.8600^{* *}$ & $131.4^{*}$ \\
Treat. & 3 & $0.848^{*}$ & $25.262^{*}$ & $0.4425^{* *}$ & $17.0025^{* *}$ & $1193.58^{* *}$ \\
Rep* treat & 6 & $0.451^{*}$ & $0.0050^{*}$ & $0.0001^{* *}$ & $0.4000^{* *}$ & $701.15^{* *}$ \\
Error & 16 & $0.002^{*}$ & 0.01 & 0.001 & 0.040 & 0.66 \\
Total & 11 & 1.510 & 25.692 & 0.5225 & $18.2526^{*}$ & 2023.31 \\
\hline
\end{tabular}


Different concentrations of Grapefruit's peel extract

UV-VIS activity of various concentrations of Grapefruit's peel extract of synthesized AgNPs is showed that the best concentration is 20:80 (see Figure. 4).

\section{X-ray Diffraction analysis (XRD)}

XRD confirmed the presence of silver nanoparticles (see Figure. 5).

\section{Transmission electron microscopy (TEM)}

AgNPs size was conducted to be $50-65$ $\mathrm{nm}$ (TEM) which was according to XRD analysis (see Figure. 6).

The overall results of this study revealed that silver nanoparticles foliar application reduced $R$. solani derived damages in cucumber plants with a considerable increase in scavenging SOD enzymes activity. Different concentrations of silver nanoparticles elicited plant defense responses at different rates. As shown in Table. 1, there is a

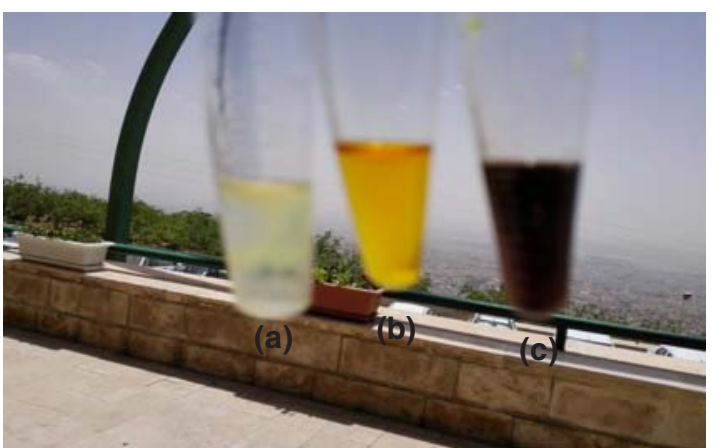

Fig. 1. a. Silver Nitrate Solution, b: Grapefruit's peel extract, c: Synthesis of Silver Nanoparticles significant difference between treatments of silver nanoparticles, at the level of $1 \%$.

\section{The effect of silver nanoparticles on growth performance}

Growth factors such as shoot and root fresh weights in significantly different from treated plants with silver nanoparticles. According to result, shoot fresh weight was appeared in infected plants with fungi $(1.7 \mathrm{~g})$, while the maximum plants fresh weight was seen in $70 \mathrm{~g} \mathrm{~L}^{-1}$ silver nanoparticles treatment $(4.6 \mathrm{~g})$. Furthermore, the highest root fresh weight $(0.8 \mathrm{~g})$ was belongs to the treatment with $70 \mathrm{gL}^{-1}$ silver nanoparticles, as well, whereas it was $0.3 \mathrm{~g}$ on infected plant $R$. solani. In addition, as it can be observed in the Fig. 7, there is a positive correlation between silver nanoparticles concentration and root/shoot fresh weight increase (Figure.7 and 8).

As shown in Fig. 8. The similar results have been observed for shoot / root dry weights of the plants.

\section{Effect of silver nanoparticles on SOD enzymes activity}

As a means to check whether the reduced disease symptoms were associated with higher accumulation of scavenging antioxidant enzyme, including SOD were investigated. Results revealed that SOD enzyme exhibited a significant dosedependent increase with silver nanoparticles application (Table 2). The results indicated that compared with the control plants, the highest SOD activity was recorded in plants treated with $70 \mathrm{gL}^{-1}$ silver nanoparticles at $48 \mathrm{~h}$ and then the enzyme was reduced (see Figure. 9).

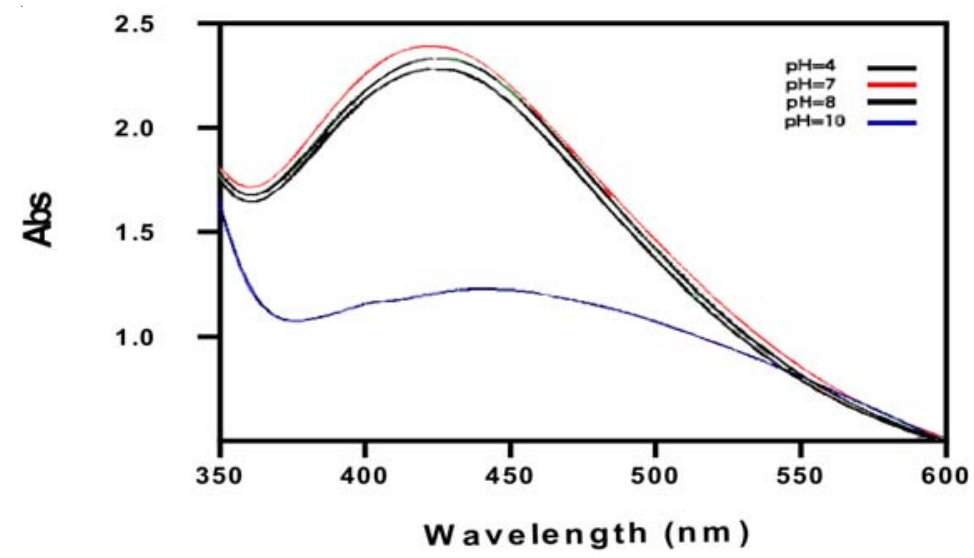

Fig. 2. Effect of different pH for green synthesis of silver nanoparticles 


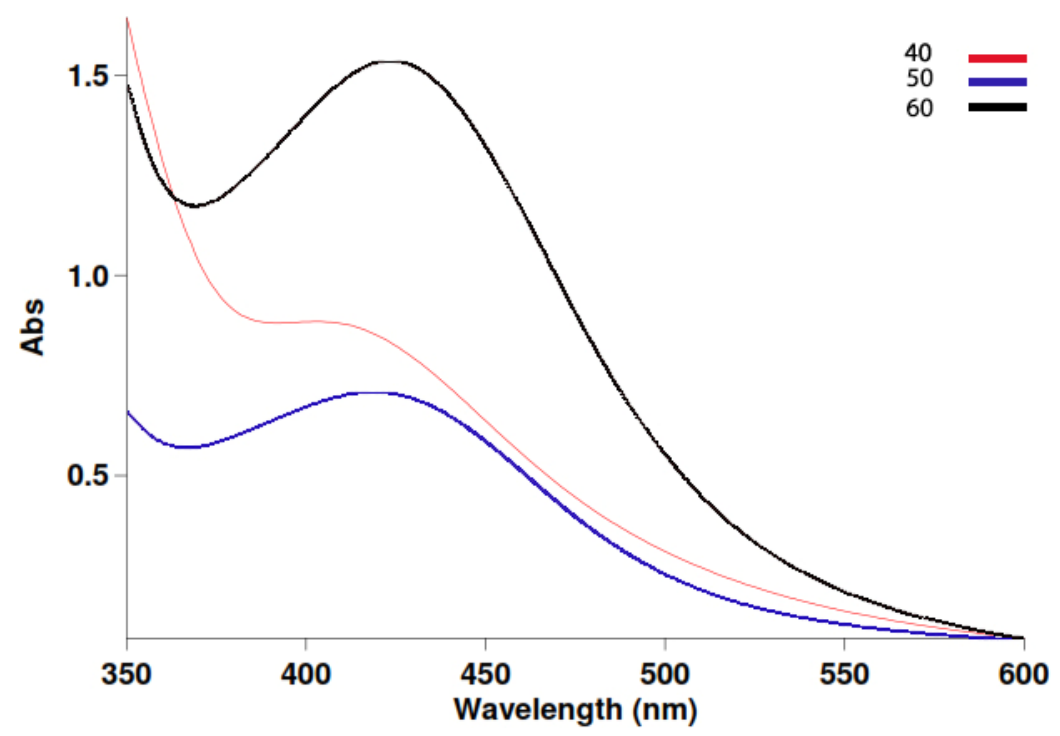

Fig. 3. Effect of different Temperature for green synthesis of silver nanoparticles

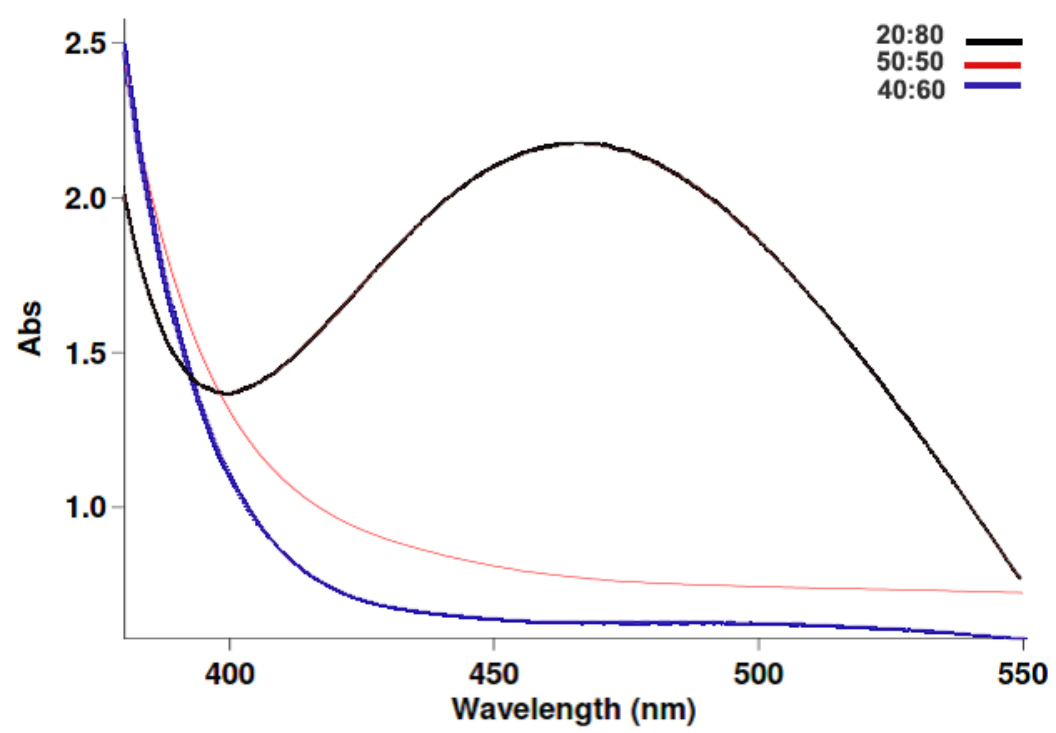

Fig. 4. Effect of different concentrations for green synthesis of silver nanoparticles

\section{DISSCUTION}

Silver nanoparticles because of their unique characteristics, can be widely used in horticulture. Many plants have scrap parts that are capable of producing nanoparticles, but still remain unknown or have not been tested yet ${ }^{30,31}$.

In the present study, we investigate nanoparticles production, time and methods of assessment of particles by aqueous extract and plant extract grapefruit peel. In addition, antifungal effects of nanoparticles on $R$. solani were evacuated.

This study showed that flavonoid extracts of grapefruit peel has a high potential for reduction of the silver nanoparticles and it is suitable for production silver nanoparticles. It was relieved that the size of nanoparticle was $5-65 \mathrm{~nm}$ and the average size was determined $55.02 \mathrm{~nm}$ with shape of spherical. The highest antifungal effect was seen 
in the treatment with $70 \mathrm{gL}^{-1}$ nanosilver. The rate of superoxide dismutase activity was significantly higher in the plants treated with $70 \mathrm{gL}^{-1}$ nanoparticles. Hence, it revealed that nanosilver damaged the $R$. solani comparison with control. Due to the Antifungal effect of silver nanoparticles on $R$. solani, it can be a good choice for control cucumber plants inoculated with $R$. solani and consequently it can be control of damping off also demonstrated that silver nanoparticles can alleviate adverse effects of $R$. solani in cucumber plants allowing them grow in a near-normal style.

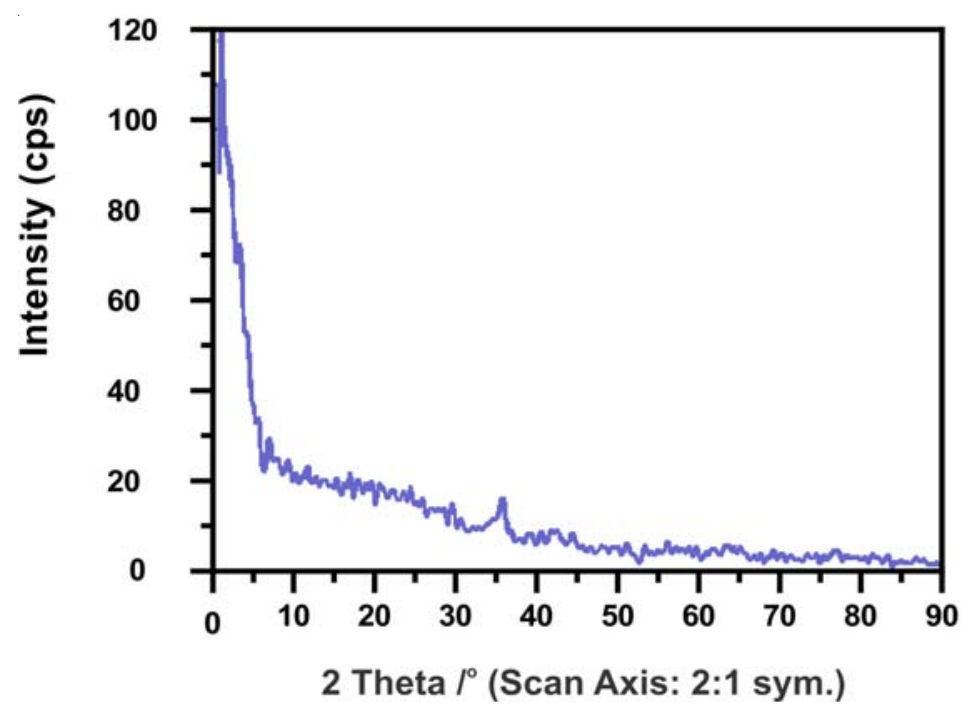

Fig. 5: XRD pattern of Ag nanoparticles using Grapefruit's peel extract
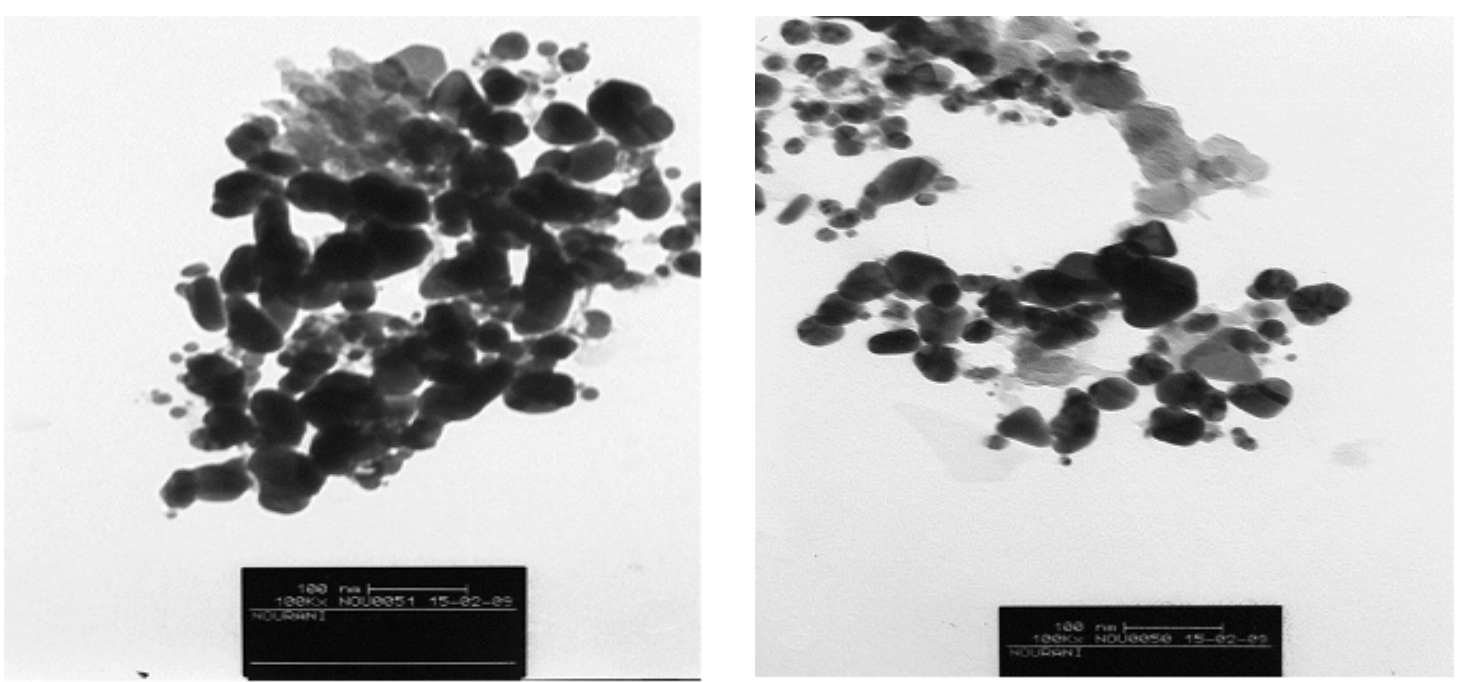

Fig. 6. TEM images of silver nanoparticles synthesized by using Grapefruit's peel extract

Jafari emamkandi et al, applied silver nanoparticles on Raphanus Sativus. They found that growth factor was strongly influenced by the concentration of nanoparticles. The antifungal action of silver nanoparticles on penicillium chrysogenum was more than copper nanoparticles ${ }^{31}$. Mazhari and Behniafar produced silver nanoparticles from from leaves extract of Pomegrante ${ }^{32}$. The UV-Visible spectrum has shown a peak appeared at $428 \mathrm{~nm}$ corresponding to the Plasmon absorbance of the AgNPs.

Time of silver nanoparticles produced was 2 and $3 \mathrm{~h}$ by aqueous extract of grapefruit peel which was not according to other studies on other plants. It could be due to the different experimental conditions of the nanoparticles. For example, this time was $2 \mathrm{~h}$ in the case of Aloe vera ${ }^{33}$. 


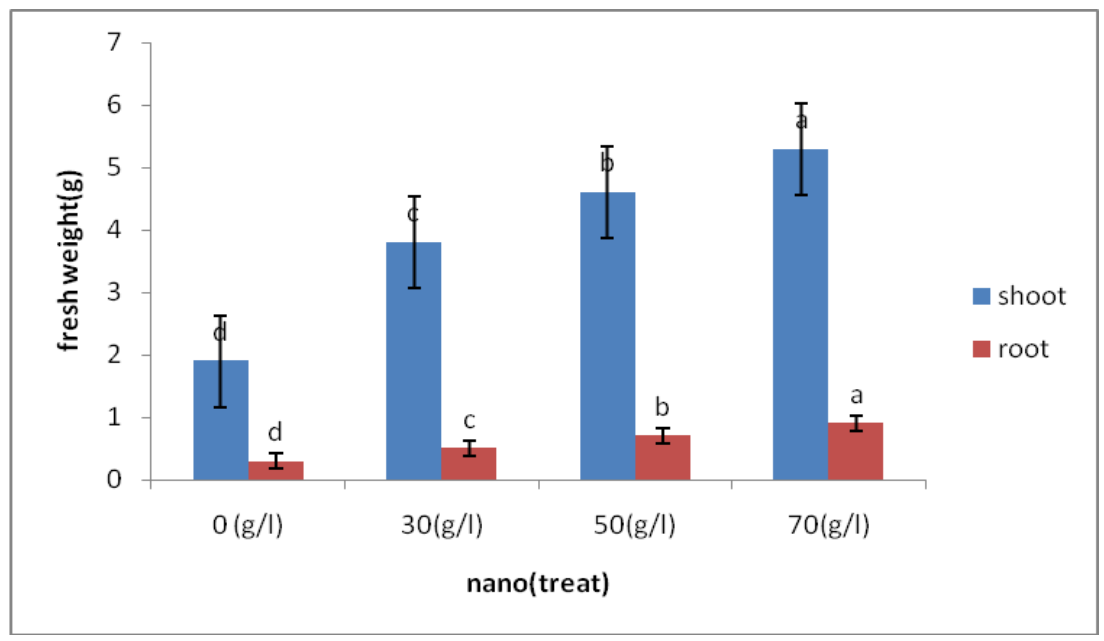

Fig. 8. Effect of silver nanoparticles on shoots and root dry weight of cucumber seedlings challenged with $R$. solani

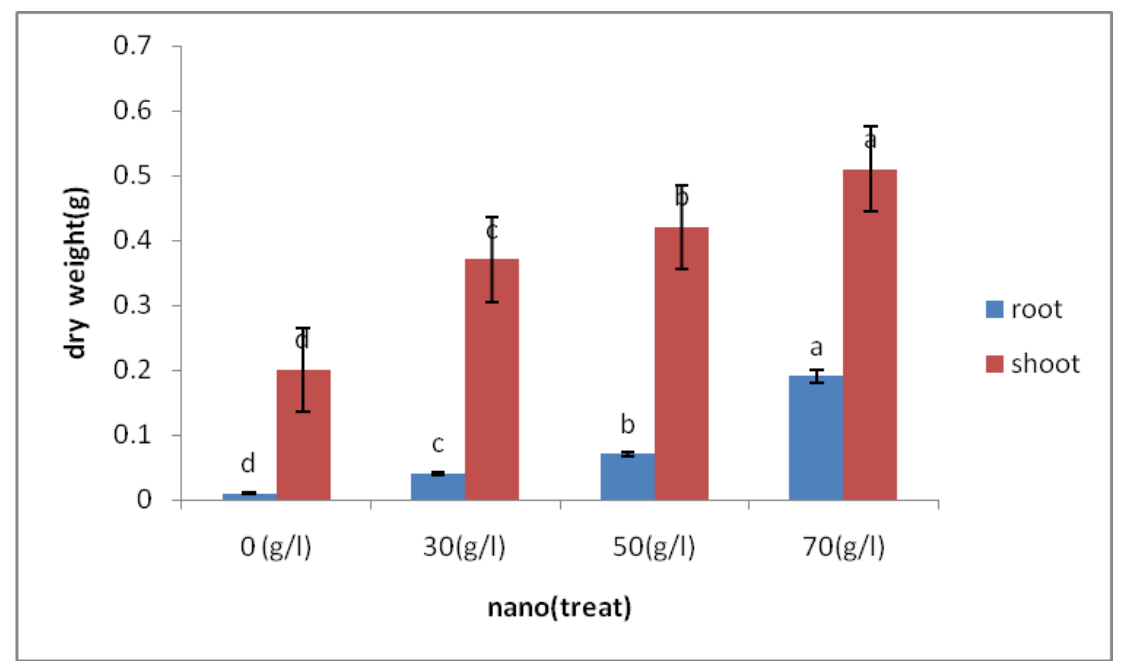

Fig. 7. Effect of silver nanoparticles on shoot and root fresh weight of cucumber seedlings challenged with $R$. solani

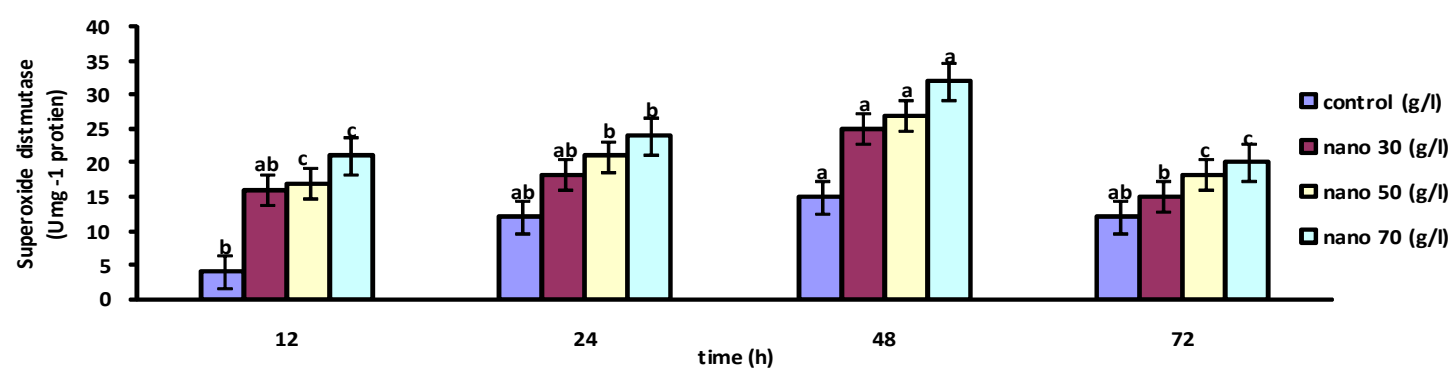

Fig. 9: Effect of silver nanoparticles on superoxide dismutase (SOD) activity over time in the leaves of cucumber plants inoculated with $R$. solani 
After color change in the reaction, spectrophotometric study conducted that maximum absorption rate was at $420 \mathrm{~nm}$. In addition, the absorption rate plays an important role for nanoparticles concentration in solution. Higher absorption, have been indicating the increased nanoparticles in a solution. Ahmed et al proved that color change is a function of passing time and reaction, there or concentration of silver nanoparticles will be enhanced ${ }^{34}$. They measured optical density reaction solution at intervals different. As a result, the solution color changes to dark brown.

X-ray diffraction was to confirm the production of nanoparticles. Each crystal has its own unique X-ray diffraction pattern. By this method, we can detect metal element of same composition of metal. As the results showed, there were peaks elements and compounds in the environment reactions, which related to the extracts. Although among these compounds, silver element clearly recognized.

In the following research, produced transmission electron microscopy (TEM) was used to determine the shape and size of nanoparticles. Nanoparticles were observed in spherical shape. There was no rod-shaped or triangular. Electronic micrographs indicated confirm the fact that the sizes of nanoparticles are very varied (5-65 nm). This result is consistent with Shankar et al., ${ }^{33}$ in the production of silver nanoparticles by Azadirachta indica. They reported the size of nanoparticles 5 to $35 \mathrm{~nm}$ and in spherical. Krishnaraj et al. stated the size of nanoparticles 20 to $30 \mathrm{~nm}^{35}$.

Antimicrobials activity of silver nanoparticles is one of the important applications. Although the exact method of preventing microbial growth by silver nanoparticles are not clearly understood, but probably several methods could be effective. Pal et al., concluded that silver nanoparticles in spherical are more than other forms, which can effect on bacteria ${ }^{36}$. Therefore, in addition to size, the nanoparticles shape is involved its antimicrobial properties. Lethal effects of silver nanoparticles are due to the ability to penetrate the cytoplasm membrane and cell wall, RNA and DNA damage, cell respiration ${ }^{37}$.

Silver is known for its antimicrobial effects and silver nanoparticles are gaining their importance due to their antimicrobial activities. Our results indicated that nanoparticle exhibit antimicrobial effect against $R$. solani. Plant-AgNPs showed a higher antioxidant and antimicrobial activity compared to other treatment. These results are agreed with finding Mohamed et al., ${ }^{38}$.

Our results demonstrate that increasing nanosilver concentration did not increase fungal growth, which is consistent with research by Sahar Ouda, which indicates that nanosilver reduced the growth of microorganisms ${ }^{39}$.

\section{REFERENCES}

1. Beyer, E.M. Effect of Silver Ion, Carbon Dioxide, and Oxygen on Ethylene Action and Metabolism. Plant Physiol. 1976, 63, 169-173.

2. Kouvaris, P.; Delimitis, A.; Zaspalis, V.; Papadopoulos, D.; Tsipas, S.A.; Michailidis, N. Green synthesis and characterization of silver nanoparticles produced using Arbutus Unedo leaf extract. Mater. Lett. 2012, 76, 18-20.

3. Gurunathan, S.; Kalishwaralal, K.; Vaidyanathan, R.; Deepak, V.; Pandian, S.R.K.; Muniyandi, J. Biosynthesis, purification and characterization of silver nanoparticles using Escherichia coli. Colloids Surf B Biointerfaces. 2009, 74, 328-335.

4. Maribel, G.G.; Jean, D.; Stephan, G. Synthesis of silver nanoparticles by chemical reduction method and their antibacterial activity. Inter $J$ Chem and Biol Eng. 2009, 2, 104-111.

5. Mohanpuria, P.; Rana, N.K.; Yadav, S.K. Biosynthesis of nanoparticles: technological concepts and future applications. J Nanopart Res. 2008, 10, 507-17.

6. Dhillon, G.S.; Brar, S.K.; Kaur, S.; Verma, M.; Green approach for nanoparticle biosynthesis by fungi: current trends and applications. Crit Rev Biotechnol. 2012, 32, 49-73.

7. Gericke, M.; Pinche, A. Biological synthesis of metal nanoparticles. Hydrometallurgy. 2006, 83, 132-40. 
8. Kaler , A.; Nankar, R.; Bhattacharyya, M.S.; Banerjee, U.C. Extracellular biosynthesis of silver nanoparticles using aqueous extract of Candida viswanathii. J Bionanosci. 2011, 5, 53-8.

9. Korbekandi, H.; Iravani, S.; Abbasi, S.P.; Production of nanoparticles using organisms. Crit Rev Biotechnol. 2009, 29, 279-306.

10. Mandal, D.; Bolander, M.E.; Mukhopadhyay, D.G.; Sarkar, P.; Mukherjee, S. The use of microorganisms for the formation of metal nanoparticles and their application. Appl. Microbiol. Biotechnol. 2006, 69, 485-492.

11. Mukherjee, P.; Roy, M.; Mandal, B.P.; Dey, G.K.; Mukherjee, P.K.; Ghatak, J.; Tyagi, A.K.; Kale. S.P. Green synthesis of highly stabilized nanocrystalline silver particles by a nonpathogenic and agriculturally important fungus T. asperellum. Nanotechnology. 2008, 22, 33-45.

12. Ahmad, A.; Mukherjee, P.; Senapati, S. D.; Mandal, M.I.; Khan, R.; Kumar, M.; Sastry.S. Extracellular biosynthesis of silver nanoparticles using the fungus Fusarium oxysporum. Colloids Surf B: Biointerfaces. 2003, 28, 313-318.

13. Klaus-Joerger, T.; Joerger, R.; Olsson, E. Granqvist. Bacteria as workers in the living factory: metal accumulating bacteria and their potential for materials science. Trends Biotechnol. 2011, 9, 15-20.

14. Krishnaraj, C.; Jagan, E.; Rajasekar, S.; Selvakumar, P.; Kalaichelvan, P.; Mohan, N. Synthesis of silver nanoparticles using Acalypha indica leaf extracts and its antibacterial activity against water borne pathogens. Colloids Surf B Biointerfaces. 2010, 76, 50-6.

15. Ahamed, M.; Khan, M.; Siddiqui, M.; AISalhi, M.S. Alrokayan. Physica E Low Dimens Syst Nanostruct. 2011, 43, 1266-71.

16. Chandran, S.P.; Chaudhary, M.; Pasricha, R,; Ahmad, A.; Sastry, M. Synthesis of gold nanotriangles and silver nanoparticles using Aloe vera plant extract. Biotechnol progress. 2006, 22, 577-583

17. Kasthuri, J.; Veerapandian, S.; Rajendiran, N. Biological synthesis of silver and gold nanoparticles using apiin as reducing agent. Colloids Surf B Biointerfaces. 2009, 68, 55-60.

18. Ankanna, S.; Prasad, T.N.; Elumalai, E.K.; Savithramma, N.; Production of biogenic silver nanoparticles using Boswellia ovalifoliolata stem bark. Dig J Nanomater Biostruct. 2010, 5, 369-72.

19. Jain, D.; Daima, H.K.; Kachhwaha, S.; Kothari, S. Synthesis of plant mediated silver nanoparticles using papaya fruit extract and evaluation of their antimicrobial activities. Dig J Nanomater Biostruct. 2009, 4, 557-63.

20. Huang J.; Li, Q.; Sun, D.; Lu, Y.;Yang, Y.;Wang, X.; Wang, H.; Shao, Y.; He, W. NBiosynthesis of silver and gold nanoparticles by novel sundried Cinnamomum camphora leaf. Nanotechnology. 2007, 18, 105-104.

21. Jiang J.; Oberdorster, G.; Biswas, P.; Characterization of size, surface charge and agglomeration state of nanoparticle nanopart Res. 2009, 11:77-89.

22. Feldheim, D.L. Foss CA. Metal nanoparticles: Boca Raton, FL; CRC Press. 2002

23. basics and applications. Hannover: Vincentz. 2008

24. Metal nanoparticles in microbiology. Berlin: Springer. 2011, 177-97.

25. Schaffer, B.; Hohenester, U.; Trugler, A.; Hofer, F. High resolution surface plasmon imaging of gold nanoparticles by energyfiltered transmission electron microscopy. Phys Rev. 2009, 79 (article 041401).

26. Machinandiarena, M.F.; Lobato, M.C.; Feldman, M.L.; Daleo, G.R.; Andreu, A.B. Potassium phosphite primes defense responses in potato against Phytophthor infestans. J. Plant Physiol. 2012, 169, 1417-1424.

27. Buczacki, S.; Harris, K. Diseases and Disorders of Garden Plants, Collins. 1998, 481-2.

28. Giannopolitis, N.S.K. Ries. Superoxide dismutase. I. Occurrence in higher plants. Plant Physiol. 1977, 59, 309-314

29. Bradford, M.M. A rapid and sensitive method for the quantitative titration of microgram quantities of protein utilizing the principle of protein-dye binding. Analyt Biochem. 1976,72, 248-254.

30. Zhang, W.; Dick, W.A.; Hoitink, H.A.J. Compost-induced systemic acquired in cucumber to Pythium root rot and anthracnose. Phytopathology. 1996, 86, 1066-1070

31. Jafari emamkandi, A.; Farhadi, K.H.; 
Pourakbar, L.; Mohammadgholizad, L.; The synthesis of metal nanoparticles using several medicinal plants and their effects on Raphanus Sativus and microorganism growth factors. Master thesis, Uremia university. 2013.

32. Mazhari, B.; Behniafar, H. Biosynthesis of Silver Nanoparticles using Leaf Extract of Pomegranate, 2th Congress of Science and innovative technologies, Kharazmi university. 2001, 1-4

33. Shankar, S.S.; Rai, A.; Ahmad, A.; Sastry, M. Rapid synthesis of $\mathrm{Au}, \mathrm{Ag}$, and bimetallic $\mathrm{Au}$ core-Ag shell nanoparticles using Neem (Azadirachta indica) leaf broth. $J$ Colloid Interface Sci. 2004, 275, 496-502

34. Ahmad, N.; Sharma, S.; Alam, M.K.; Singh, V.N.; Shamsi, S.F.; Mehta, B.R. Rapid synthesis of silver nanoparticles using dried medicinal plant of basil. Colloids and surfaces B, Biointerfaces. 2010, 81, 81-86

35. Krishnaraj, C.; Jagan, E.G.; Rajasekar, S.; Selvakumar, P.; Kalaichelvan, P.T.; Mohan.
N. Synthesis of silver nanoparticles using Acalypha indica leaf extracts and its antibacterial activity against water borne pathogens. Colloids and surfaces $B$, Biointerfaces. 2010. 76, 50-56.

36. Pal, S.; Y.K. Tak.; Song, J.M. Does the antibacterial activity of silver nanoparticles depend on the shape of the nanoparticle? a study of the Gram, negative bacterium Escherichia coli. Appl Environ Microbiol. 2007, 17, 12-20.

37. Klasen, H.J. A historical review of the use of silver in the treatment of burns. I. early uses. Burns. 2000, 26, 117-30.

38. Abdel-Aziz, M.S.; Shaheen, M.S.; El-Nekeety A.A.; Abdel-Wahhab. M.A. Antioxidant and antibacterial activity of silver nanoparticles biosynthesized using Chenopodium murale leaf extract. J Saudi Chemi Society. 2014, 18, 356-363

39. Saharouda, M. Antifungal Activity of Silver and Copper Nanoparticles on Two Plant Pathogens, Alternaria alternata and Botrytis cinerea. Res J Microbiol. 2014, 9, 34-42. 